\title{
Optimization of brandy base wine production technique using ginger pomace
}

\author{
Chu Bao ${ }^{1}$, Jin Yuhong ${ }^{1 *}$, Gao Aiying ${ }^{2}$, Wu Shuai ${ }^{3}$ \\ ${ }^{1}$ Key Laboratory of Food Processing Technique and Quality Control in Shandong Province, College of Food Science and Engineering, \\ Shandong Agricultural University, Tai'an 271018, Shandong Province, China \\ 2 Taian Institute for Food and Drug Control, Tai'an Shandong 271000, Shandong Province, China \\ ${ }^{3}$ Yantai Inspection and Testing Center for Food and Drug, No.6 Haibo Road, Yantai, 264000, Shandong Province, China
}

\begin{abstract}
In this work, the effects of ginger pomace/water ratio, yeast strain selection, sugar and yeast addition, fermentation temperature on the physicochemical properties and sensory evaluation of ginger brandy and its base wine was investigated to optimize production technique. It was found that the $\mathrm{pH}$ and total acidity of ginger brandy base wine were mainly influenced by ginger pomace/water ratio, yeast strain, sugar and yeast addition, fermentation temperature. Gingerol content was mostly affected by ginger pomace/water ratio. The results of electronic nose analysis showed that main aroma components of ginger pomace brandy were mainly affected by ginger pomace/water ratio. In general, the optimized production technique was ginger pomace/water ratio at 1:3, 3\# yeast strain, sugar and yeast addition $(102 \mathrm{~g} / \mathrm{L}$ and $0.40 \mathrm{~g} / \mathrm{L})$, fermentation temperature $\left(18^{\circ} \mathrm{C}\right)$. Ginger brandy base wine made by above technique after second full distillation could produce ginger brandy with typical, strong and balanced ginger aroma, mellow and full-bodied taste, and long aftertaste.
\end{abstract}

\section{INTRODUCTION}

China is the main country of ginger production in the world, rich in resources, with a total planting area of $285,300 \mathrm{hm}^{2}$. The production from 2016 to 2020 are $9,380,000, \quad 8,930,000,8,460,000, \quad 7,620,000$ and $9,190,000$ tons, respectively [1]. Ginger is a medicinal and edible plant that originated in Southeast Asia and has been cultivated for thousands of years [2]. Ginger contains 3\%$6 \%$ fat, $9 \%$ protein, $60 \%-70 \%$ carbohydrate, $3 \%-8 \%$ crude fiber, $9 \%-12 \%$ water, and $2 \%-3 \%$ volatile oil [3]. In addition to edible nutrition, it also has medicinal ingredients such as gingerol, polysaccharides, etc [4]. Gingerol is the main medicinal component of ginger and has a wide variety, mainly including zingiberone, 6gingerol, 6-shogaol, 8-gingerol, and 10-gingero 1[5]. According to previous study, 6-gingerol has a therapeutic effect on LTA-induced mastitis. When the concentration of 6-gingerol is $20 \mu \mathrm{M}$, it can significantly reduce inflammatory cells, cytokines and reactive oxygen species, promote the proliferation of glandular cells, and reduce the damage to the breast [6]. At present, ginger extract has been successfully used in lowering blood sugar [7], antiinflammatory [8], anti-cancer [9], and antioxidant [10]. These medicinal effects can increase the value of ginger.

As a condiment, ginger has a special aroma. Huang et al. identified 60 volatile components from dried ginger using GC-MS, including zingiberene (26.4\%-37.1\%), $\beta$ phellandrene $\quad(7.4 \%-12.9 \%), \quad \beta$-sesquiphellandrene $(10.2 \%-12.8 \%)$, and geranial $(6.6 \%-8.1 \%)$ [11]. Due to its rich nutrition and aroma, ginger has been made into various products, such as ginger juice, tea and preserved ginger. At present, most ginger products are made with ginger juice. The by-product of ginger juice, ginger pomace, contains various active ingredients, such as ginger essential oil, gingerol, and dietary fiber. This study intends to use ginger pomace to make a ginger pomace brandy with typical, strong ginger aroma and balanced taste. In our study, the effects of ginger pomace/water ratio, yeast strain selection, sugar and yeast addition, fermentation temperature on the physicochemical properties and sensory evaluation of ginger brandies and its base wine was investigated to optimize their production technique.

\section{MATERIALS AND METHODS}

\subsection{Materials}

Ginger pomace purchased from Yijiakang Food Company (Qingzhou, Shandong), sugar purchased from the local market (Taian, Shandong), Saccharomyces cereviaiae, purchased from Lallemand Company (Toulouse France) were labeled as $1 \#, 2 \#, 4 \#, 5 \#$, another one purchased from Eaton (Langenlonshein Germany) was labeled as 3\#. 


\subsection{Experimental methods}

\subsubsection{Preparation of ginger pomace base wine and brandy}

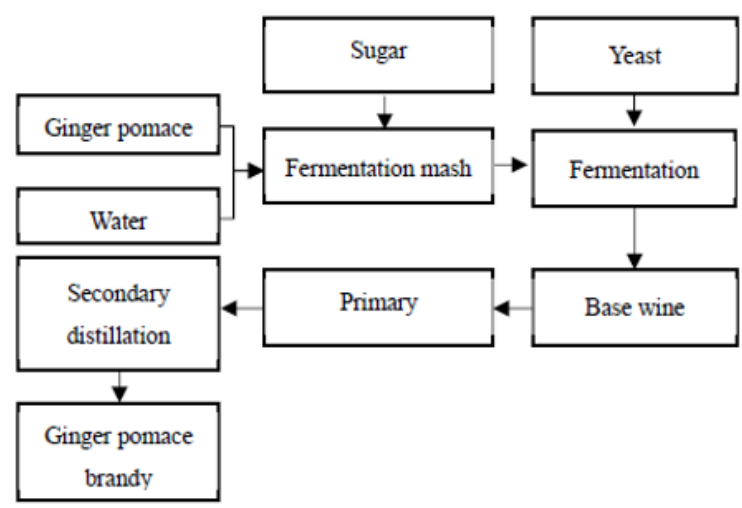

\subsubsection{Selection method of optimum ginger pomace/water ratio}

Fermention mash was prepared according to ginger pomace/water ratio $=1: 1,1: 2,1: 3,1: 4,1: 5$, respectively. The sugar content was adjusted to $102 \mathrm{~g} / \mathrm{L}$, and yeast was inoculated at $0.4 \mathrm{~g} / \mathrm{L}$, and fermented at $20^{\circ} \mathrm{C}$. The total sugar, reducing sugar, alcohol content, $\mathrm{pH}$ and total acidity of five base wines were determined, and the alcohol content, total acid, total ester and volatile acids of five kinds of brandies were determined. The sensory quality was analyzed and evaluated. The highest sensory score was selected as the best ginger pomace/water ratio.

\subsubsection{Selection method of the best yeast strain}

$1 \#, 2 \#, 3 \#, 4 \#$ and $5 \#$ yeasts were added to fermention mash, respectively, under the optimum conditions of ginger pomace/water ratio. The sugar content was adjusted to $102 \mathrm{~g} / \mathrm{L}$, The yeast addition was $0.4 \mathrm{~g} / \mathrm{L}$, and the fermentation temperature was $20^{\circ} \mathrm{C}$. The same indexes of the five base wines and brandies were done as 2.2.2. The highest sensory score was selected as the most suitable yeast strain.

\subsubsection{Determination of optimum sugar content in fermentation mash}

Under the optimum conditions of ginger pomace/water ratio, the sugar content of fermentation mash was adjusted to $85 \mathrm{~g} / \mathrm{L}, 102 \mathrm{~g} / \mathrm{L}, 119 \mathrm{~g} / \mathrm{L}, 136 \mathrm{~g} / \mathrm{L}$ and $153 \mathrm{~g} / \mathrm{L}$, respectively, and the most suitable yeast strain was used.
The same indexes analysis was done as 2.2.2 of the base wine and brandy. The highest sensory score was selected as the most suitable sugar content.

\subsubsection{Determination of optimum yeast addition}

Under the optimum conditions of ginger pomace/water ratio, the most suitable yeast strain and sugar content were added to the fermentation mash. And the addition of yeast was adjusted to $0.25 \mathrm{~g} / \mathrm{L}, 0.3 \mathrm{~g} / \mathrm{L}, 0.35 \mathrm{~g} / \mathrm{L}, 0.4 \mathrm{~g} / \mathrm{L}, 0.45$ $\mathrm{g} / \mathrm{L}$, respectively, The fermentation temperature was $20^{\circ} \mathrm{C}$. Then the same indexes analysis was done as 2.2.2. The highest sensory score was selected as the most suitable yeast addition.

\subsubsection{Determination of optimum fermentation temperature of base wine}

Under the optimum conditions of ginger pomace/water ratio, the most suitable yeast strain, sugar content, and yeast addition were added to the fermention mash. And the fermention mash was fermented at $16^{\circ} \mathrm{C}, 18^{\circ} \mathrm{C}, 20^{\circ} \mathrm{C}$, $22^{\circ} \mathrm{C}$ and $24^{\circ} \mathrm{C}$ respectively. The same indexes of the five base wines and brandies were done as 2.2.2. The highest sensory score was the best fermentation temperature.

\subsection{Analysis method}

\subsubsection{Determination of physicochemical indexes of ginger pomace base wine and brandy}

The determination methods of alcohol content, total sugar, total acidity and $\mathrm{pH}$ of ginger pomace base wine were according to GB/T15038-2006 General analysis method for wine and fruit wine. The determination methods of precision, total acidity, total ester and volatile acids of ginger pomace brandy wine were according to GB/T11856-2008 Brandy.

\subsubsection{Electronic nose measurement method}

Electronic nose measurement method were according to Adelina's method[12] with slight modifications. $1 \mathrm{~mL}$ of ginger pomace brandy was diluted five times and added to $25 \mathrm{~mL}$ headspace bottle, stilled at $20^{\circ} \mathrm{C}$ for 20 minutes, and then determined. Each sample was measured three parallel.

\subsubsection{Sensory evaluation and Rank-rating}

Sensory evaluation was according to GB/T 10220 Summary of sensory analysis methodology and GB/T 11856-2008 Brandy, and detailed assessment was shown in Table 1.

Table 1. Sensory evaluation standard of Ginger pomace brandy

\begin{tabular}{cc}
\hline & Sensory evaluation \\
\hline Appearance $\left(10^{\prime}\right)$ & Whether the appearance was colorless, clear and shiny, without sundries, \\
turbidity
\end{tabular}




Taste $\begin{aligned} & \text { Whether the taste was sweet, mellow, delicate, full, continuous, harmonious, } \\ & \left(40^{\prime}\right)\end{aligned}$
$\begin{aligned} & \text { Typical } \\ & \left(20^{\prime}\right)\end{aligned}$
Whether the ginger spicy taste was heavy, suitable or insufficient, whether there was a
miscellaneous flavor

Sensory evaluation method: five samples were sent to 11 qualified cuppers in random order, and the cuppers were asked to evaluate the appearance, aroma, taste and typicality of the samples according to Table 1.

Rank-rating was represented accoding to the sensory score as well as the quality of the five samples. By sorting, the rank sum and $\mathrm{T}$ value were calculated. The significant difference between different samples was obtained by comparing with the critical value Table of Friedman test[13] and the LSRD[13] value of Fishers[13]. And the samples with low rank sum were more favored by the cuppers.

\subsection{Statistical analysis.}

The experimental data were analyzed by Excel 2016 and IBM SPSS Statistics 25. Each experiment was paralleled three times and the results were expressed as mean \pm standard deviation and different letters in each row mean significant difference $(\mathrm{p}<0.05)$.

\section{RESULTS AND DISCUSSIONS}

\subsection{Effects of ginger pomace/water ratio on the physicochemical properties and sensory evaluation of ginger brandy and its base wine}

\subsubsection{Effects of ginger pomace/water ratio on the physicochemical properties of ginger brandy and its base wine}

Physicochemical properties of ginger pomace brandy and its base wine with five different ginger pomace/water ratios were shown in Table 2. The ginger pomace/water ratio affected the $\mathrm{pH}$ and total acid of ginger pomace brandy base wine. The $\mathrm{pH}$ of the base wine had the same change trend as the total acidity. As ginger pomace/water ratio increased, the total acidity decreased and the $\mathrm{pH}$ increased. When ginger pomace/water ratio at 1:5, the highest $\mathrm{pH}$ was 3.67 , and the lowest total acidity was 5.64 $\mathrm{g} / \mathrm{L}$. Ginger pomace/water ratio also had an important effect on the gingerol content, when ginger pomace/water ratio increased, gingerol content decreased significantly. The total acidity of ginger pomace brandy correlated well with its base wine $(\mathrm{r}=0.889, \mathrm{p}<0.05)$. After alcohol contents of the brandy were adjusted to the same level, when ginger pomace/water ratio was at 1:1, when ginger pomace/water ratio was at 1:5, the highest total acidity and ester were $0.25 \mathrm{~g} / \mathrm{L}$ and $0.95 \mathrm{~g} / \mathrm{L}$, respectively. The lowest total acidity and esters content was $0.22 \mathrm{~g} / \mathrm{L}$ and $0.93 \mathrm{~g} / \mathrm{L}$, respectively. Total ester, total acidity and volatile acids decreased with the increasing of ginger pomace/water ratio.

\subsubsection{Principal component analysis of ginger pomace brandy with different ginger pomace/water ratios by using electronic nose}

Principal component analysis of ginger pomace brandy with different ginger pomace/water ratios by using electronic nose was presented in the Figure 1. The contribution rate of the first principal component (PC1)

Table 2 Physicochemical properties of ginger pomace brandy and its base wine with different ginger pomace/water ratio

\begin{tabular}{|c|c|c|c|c|c|c|}
\hline & & \multicolumn{5}{|c|}{ Ginger pomace/water ratio } \\
\hline & & $1: 1$ & $1: 2$ & $1: 3$ & $1: 4$ & $1: 5$ \\
\hline \multirow{6}{*}{ Base wine } & Alcohol content $(\%)$ & $6.03 \pm 0.01 \mathrm{e}$ & $6.52 \pm 0.00 \mathrm{a}$ & $6.23 \pm 0.00 \mathrm{~d}$ & $6.33 \pm 0.00 \mathrm{c}$ & $6.36 \pm 0.00 \mathrm{~b}$ \\
\hline & $\mathrm{pH}$ & 3.33 & 3.51 & 3.34 & 3.88 & 3.67 \\
\hline & Reducing Sugar (g/L) & $0.53 \pm 0.01 b$ & $0.50 \pm 0.00 \mathrm{c}$ & $0.45 \pm 0.00 \mathrm{~d}$ & $0.43 \pm 0.00 \mathrm{e}$ & $0.60 \pm 0.00 \mathrm{a}$ \\
\hline & Total Sugar (g/L) & $0.59 \pm 0.01 b$ & $0.51 \pm 0.00 \mathrm{c}$ & $0.51 \pm 0.00 \mathrm{~d}$ & $0.50 \pm 0.00 \mathrm{e}$ & $0.74 \pm 0.00 \mathrm{a}$ \\
\hline & Total Acidity (g/L) & $7.35 \pm 0.01 \mathrm{a}$ & $6.31 \pm 0.00 \mathrm{c}$ & $6.58 \pm 0.00 \mathrm{~b}$ & $5.98 \pm 0.00 \mathrm{~d}$ & $5.64 \pm 0.00 \mathrm{e}$ \\
\hline & Gingerol (mg/L) & $56.27 \pm 0.00 \mathrm{a}$ & $49.73 \pm 0.03 b$ & $35.43 \pm 0.03 c$ & $30.88 \pm 0.00 \mathrm{~d}$ & $28.92 \pm 0.03 \mathrm{e}$ \\
\hline \multirow{4}{*}{ Brandy } & Alcohol content $(\%)$ & 35 & 35 & 35 & 35 & 35 \\
\hline & Total Acidity (g/L) & $0.25 \pm 0.002 \mathrm{a}$ & $0.24 \pm 0.002 \mathrm{a}$ & $0.23 \pm 0.000 \mathrm{~b}$ & $0.22 \pm 0.002 b c$ & $0.22 \pm 0.002 \mathrm{c}$ \\
\hline & Total ester $(\mathrm{g} / \mathrm{L})$ & $0.95 \pm 0.002 \mathrm{a}$ & $0.93 \pm 0.002 d$ & $0.94 \pm 0.001 b$ & $0.93 \pm 0.001 \mathrm{c}$ & $0.93 \pm 0.003 \mathrm{~cd}$ \\
\hline & Volatile acids $(\mathrm{g} / \mathrm{L})$ & $0.07 \pm 0.001 \mathrm{a}$ & $0.07 \pm 0.000 \mathrm{a}$ & $0.06 \pm 0.001 \mathrm{a}$ & $0.06 \pm 0.000 \mathrm{~b}$ & $0.05 \pm 0.000 \mathrm{c}$ \\
\hline
\end{tabular}

was $96.037 \%$, while the contribution rate of the second principal component (PC2) was $1.8721 \%$, and the total contribution rate of $\mathrm{PC} 1$ and $\mathrm{PC} 2$ was $99.909 \%$, which was much higher than $85 \%$. The two principal components could represent the main volatile components of ginger pomace brandy. From the PCA load diagram, it was found that the five samples were separated from each other and there was no overlap, and it indicated that the aroma of the five ginger pomace brandies had a relatively obvious difference, and ginger pomace/water ratio had a great 
impact on the brandy aroma.

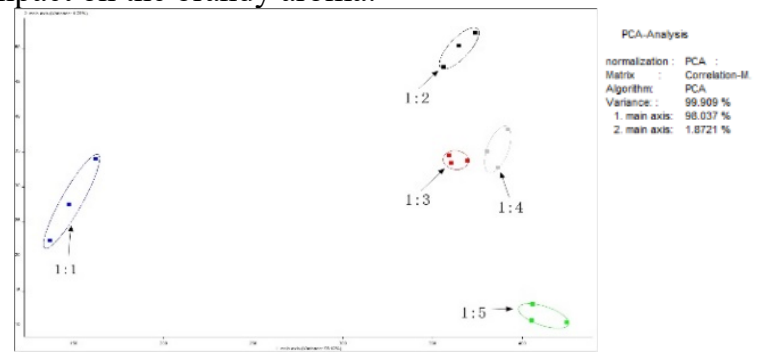

Figure 1. PCA load diagram of electronic nose analysis for ginger pomace brandy with different ginger pomace/water ratios

\subsubsection{Sensory evaluation of ginger pomace brandy with different ginger pomace/water ratios}

Sensory evaluation of ginger pomace brandy with five ginger pomace/water ratios was shown in Figure 2. Because of full distillation, ginger pomace brandies with ginger pomace/water ratios at 1:4 and 1:5 had obvious milky white turbidity, consequently these 2 brandies got low appearance scores. From the perspective of aroma, brandy with ginger pomace/water ratios at 1:1 and 1:3 had the highest scores while the brandy with ginger pomace/water ratios at 1:4 got the lowest score. For the taste, the brandy with ginger pomace/water ratios at 1:3

Table 3. Quality ranking results of five different ginger pomace/water ratios of ginger brandy by 11 qualified cuppers got the highest score while the brandy with ginger pomace/water ratios at 1:5 tasted flat and got the lowest score. For the typicality, all these five brandies had typical ginger flavor and got $100 \%$. In general, brandy with ginger pomace/water ratios at 1:3 had typical ginger aroma, balanced wine flavor, smooth taste, and proper gingerol strength, consequently, got the highest score.

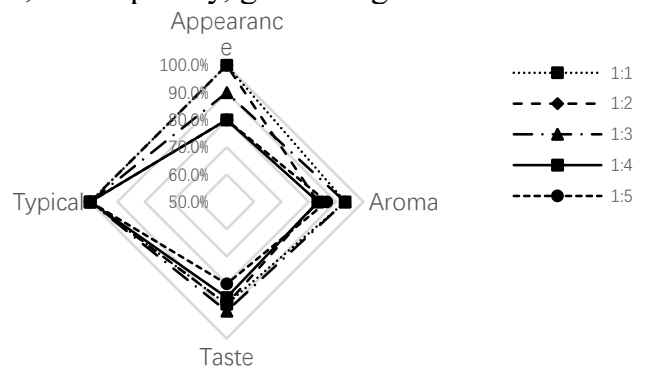

Figure 2. Radar chart of sensory score of ginger pomace brandy with different ginger pomace/water ratios

Ranking results and significant difference of the five sample were shown in Table 3. There was a significant difference between ginger pomace/water ratios at 1:5 and others. Through the sum of ranks, it could be concluded that ginger pomace brandy with fermentation temperature at $18^{\circ} \mathrm{C}$ was the most popular.

\begin{tabular}{|c|c|c|c|c|c|}
\hline \multirow{2}{*}{ Cuppers } & \multicolumn{5}{|c|}{ Ginger pomace/water ratios } \\
\hline & $1: 1$ & $1: 2$ & $1: 3$ & $1: 4$ & $1: 5$ \\
\hline 1 & 2 & 3 & 1 & 4 & 5 \\
\hline 2 & 3 & 1 & 2 & 4 & 5 \\
\hline 3 & 3 & 2 & 1 & 4 & 5 \\
\hline 4 & 4 & 2 & 1 & 3 & 5 \\
\hline 5 & 5 & 4 & 2 & 1 & 3 \\
\hline 6 & 3 & 4 & 1 & 2 & 5 \\
\hline 7 & 4 & 3 & 2 & 1 & 5 \\
\hline 8 & 3 & 5 & 1 & 2 & 4 \\
\hline 9 & 3 & 2 & 1 & 5 & 4 \\
\hline 10 & 3 & 4 & 2 & 1 & 5 \\
\hline 11 & 2 & 3 & 1 & 4 & 5 \\
\hline Sum of ranks & 35 & 33 & 15 & 31 & 51 \\
\hline Significance & $\mathrm{B}$ & B & $\mathrm{C}$ & B & $\mathrm{A}$ \\
\hline
\end{tabular}

\subsection{Effects of different yeast stains on the physicochemical properties and sensory evaluation of ginger brandy and its base wine}

\subsubsection{Effects of different yeast stains on the physicochemical properties of ginger brandy and its base wine}

The physicochemical properties of ginger brandy base wines made by five different yeast strains were shown in Table 4. In terms of alcohol content, $3 \#$ yeast could produce base wine with the highest alcohol content at 6.12 $\mathrm{g} / \mathrm{L}$, and $1 \#$ yeast could produce base wine with the highest $\mathrm{pH}$ at 3.35 and the highest total acid content at $6.75 \mathrm{~g} / \mathrm{L}$. In terms of total sugar and reducing sugar, $5 \#$ yeast could produce base wine with the highest total sugar and reducing sugar at $3.83 \mathrm{~g} / \mathrm{L}$ and $3.11 \mathrm{~g} / \mathrm{L}$, respectively. Gingerol contents in five samples were different, but the effect of different yeast strains on gingerol contents was lower than that of ginger pomace/water ratio. It was due to that the gingerol contents was mainly related to the ginger itself. After second distillation and the alcohol content of ginger pomace brandy was adjusted to $27 \%$, the $5 \#$ yeast strain could produce brandy with highest total acidity at $0.43 \mathrm{~g} / \mathrm{L}$, while the $5 \#$ yeast strain had the lowest at 0.89 $\mathrm{g} / \mathrm{L}$. Furthermore, the $1 \#$ yeast strain had the highest volatile acid content at $0.10 \mathrm{~g} / \mathrm{L}$ and $3 \#$ and $4 \#$ yeast strains shared the lowest at $0.06 \mathrm{~g} / \mathrm{L}$. 


\subsubsection{Principal component analysis of ginger pomace brandy with different yeast strains by using electronic nose}

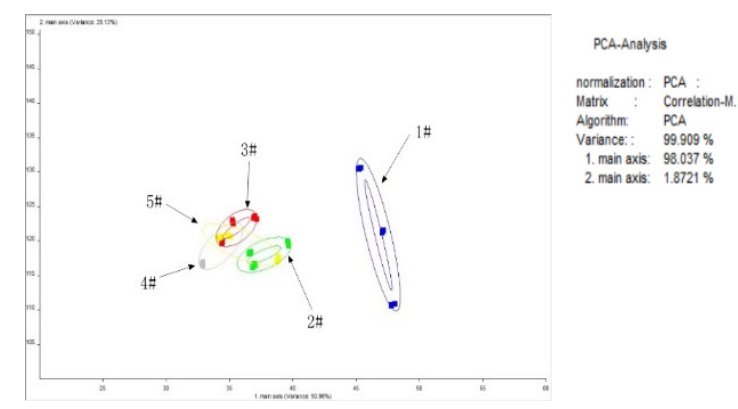

Figure 3. PCA load diagram of ginger pomace brandy electronic nose with different yeast strains

Principal component analysis of ginger pomace brandy with different yeast strains by using electronic nose was presented in the Figure 3. The contribution rate of the first principal component (PC1) was $98.037 \%$, while the contribution rate of the second principal component (PC2) was $1.87217 \%$, and the total contribution rate was $99.909 \%$, which was much higher than $85 \%$. The two principal components could represent the main volatile components of ginger pomace brandy. From the PCA load diagram, it was found that there was a significant distance between $1 \#$ yeast and the other four yeast strains. The aromas of $2 \#, 3 \#, 4 \#$, and $5 \#$ were relatively close and their PCA load diagram were partial overlapped, indicating that these 4 ginger pomace brandies were similar in aroma.

\subsubsection{Sensory evaluation of ginger pomace brandy with different yeast strains}

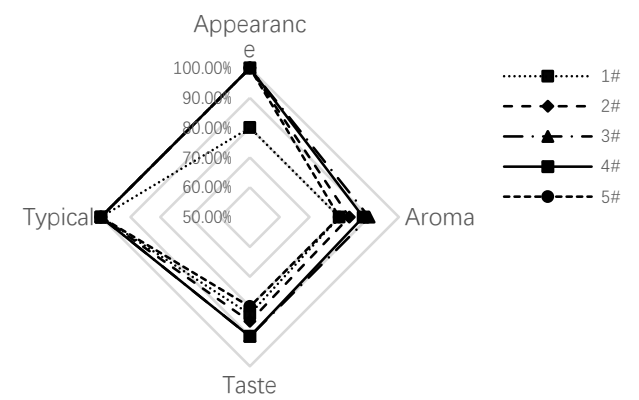

Figure 4 Radar chart of sensory score of ginger pomace brandy with different yeast strains

Table 4 Physicochemical properties of ginger pomace brandy and its base wine with different yeast strains

\begin{tabular}{|c|c|c|c|c|c|c|}
\hline & & \multicolumn{5}{|c|}{ Yeast strains } \\
\hline & & $1 \#$ & 2\# & 3\# & 4\# & 5\# \\
\hline \multirow{6}{*}{ Base wine } & Alcohol content (\%) & $6.01 \pm 0.00 \mathrm{c}$ & $6.04 \pm 0.00 \mathrm{~b}$ & $6.12 \pm 0.00 \mathrm{a}$ & $5.95 \pm 0.01 \mathrm{~d}$ & $5.92 \pm 0.02 \mathrm{e}$ \\
\hline & $\mathrm{pH}$ & 3.35 & 3.33 & 3.34 & 3.34 & 3.32 \\
\hline & Reducing Sugar $(\mathrm{g} / \mathrm{L})$ & $3.11 \pm 0.00 \mathrm{a}$ & $2.95 \pm 0.00 \mathrm{~b}$ & $2.84 \pm 0.01 \mathrm{c}$ & $2.51 \pm 0.01 \mathrm{e}$ & $2.79 \pm 0.01 \mathrm{~d}$ \\
\hline & Total Sugar $(\mathrm{g} / \mathrm{L})$ & $3.83 \pm 0.01 \mathrm{~b}$ & $3.41 \pm 0.01 \mathrm{c}$ & $3.17 \pm 0.00 \mathrm{~d}$ & $3.06 \pm 0.00 \mathrm{e}$ & $4.58 \pm 0.0 \mathrm{a}$ \\
\hline & Total Acidity $(\mathrm{g} / \mathrm{L})$ & $6.75 \pm 0.04 \mathrm{a}$ & $5.87 \pm 0.04 \mathrm{c}$ & $5.72 \pm 0.00 \mathrm{~d}$ & $5.73 \pm 0.00 \mathrm{~d}$ & $6.18 \pm 0.00 \mathrm{~b}$ \\
\hline & gingerol $(\mathrm{mg} / \mathrm{L})$ & $40.35 \pm 0.03 a$ & $38.59 \pm 0.00 \mathrm{~d}$ & $38.96 \pm 0.05 \mathrm{c}$ & $39.58 \pm 0.00 \mathrm{~b}$ & $38.12 \pm 0.03 \mathrm{e}$ \\
\hline \multirow{4}{*}{ Brandy } & Alcohol content (\%) & 27 & 27 & 27 & 27 & 27 \\
\hline & Total Acidity $(\mathrm{g} / \mathrm{L})$ & $0.35 \pm 0.007 \mathrm{~b}$ & $0.32 \pm 0.002 \mathrm{c}$ & $0.30 \pm 0.003 \mathrm{~d}$ & $0.27 \pm 0.003 \mathrm{e}$ & $0.43 \pm 0.014 a$ \\
\hline & Total ester $(\mathrm{g} / \mathrm{L})$ & $1.09 \pm 0.039 b$ & $0.95 \pm 0.002 \mathrm{c}$ & $0.95 \pm 0.003 \mathrm{c}$ & $0.89 \pm 0.034 \mathrm{~d}$ & $1.12 \pm 0.003 \mathrm{a}$ \\
\hline & Volatile acids $(\mathrm{g} / \mathrm{L})$ & $0.10 \pm 0.001 \mathrm{a}$ & $0.07 \pm 0.000 \mathrm{c}$ & $0.06 \pm 0.001 \mathrm{~d}$ & $0.06 \pm 0.004 d$ & $0.09 \pm 0.000 \mathrm{~b}$ \\
\hline
\end{tabular}

Sensory evaluation of ginger pomace brandy with five yeast strains was shown in Figure 4. In general, 1\# yeast strain got the lowest appearance score. 3\# yeast strain got the highest aroma score while the $1 \#$ and $5 \#$ scored the lowest. 3\# and 4\# got the highest taste score. All these five samples had the typical ginger flavor and scored $100 \%$. Overall, ginger pomace brandy with $3 \#$ yeast strain was the most popular and got the highest total score with typical ginger flavor, strong and balanced taste, proper gingerol strength.

Table 5. Quality ranking results of five different yeast of ginger brandy by 11 quality cuppers

\begin{tabular}{cccccc}
\hline \multirow{2}{*}{ Cuppers } & \multicolumn{5}{c}{ Different yeast strains } \\
\cline { 2 - 5 } & $1 \#$ & $2 \#$ & $3 \#$ & $4 \#$ & $5 \#$ \\
\hline 1 & 3 & 2 & 1 & 4 & 5 \\
2 & 1 & 3 & 2 & 4 & 5 \\
3 & 5 & 2 & 1 & 3 & 4 \\
4 & 4 & 3 & 1 & 2 & 5 \\
5 & 5 & 4 & 2 & 1 & 3 \\
6 & 3 & 4 & 1 & 2 & 5 \\
7 & 4 & 3 & 2 & 1 & 5 \\
8 & 3 & 5 & 1 & 2 & 4 \\
9 & 3 & 2 & 1 & 5 & 4 \\
10 & 3 & 4 & 2 & 1 & 5 \\
\hline
\end{tabular}




\begin{tabular}{cccccc}
11 & 3 & 1 & 2 & 4 & 5 \\
Sum of ranks & 37 & 33 & 16 & 29 & 50 \\
Significance & $\mathrm{AB}$ & $\mathrm{BC}$ & $\mathrm{D}$ & $\mathrm{C}$ & $\mathrm{A}$ \\
\hline
\end{tabular}

Ranking results and significant difference from the cuppers were shown in Table 5. Through the sum of ranks, it could be concluded that ginger pomace brandy with $3 \#$ yeast strains was the most popular.

\subsection{Effects of sugar addition on the physicochemical properties and sensory evaluation of ginger brandy and its base wine}

\subsubsection{Effects of different sugar addition on the physicochemical properties of ginger brandy and its base wine}

Physicochemical properties of ginger pomace brandy and its base wine with different sugar addition were shown in Table 6. The alcohol content of base wine changed with different sugar addition. The highest alcohol content was $9.05 \%$ with sugar addition of $153 \mathrm{~g} / \mathrm{L}$, and the lowest alcohol content was $5.12 \%$ with sugar addition of $85 \mathrm{~g} / \mathrm{L}$. For the total acidity and $\mathrm{pH}$, when the sugar addition was $85 \mathrm{~g} / \mathrm{L}$, the total acidity was highest at $7.75 \mathrm{~g} / \mathrm{L}$ and $\mathrm{pH}$ was lowest at 3.31. By contrast, when the sugar addition was $136 \mathrm{~g} / \mathrm{L}$, the total acidity was lowest at $6.72 \mathrm{~g} / \mathrm{L}$ and $\mathrm{pH}$ was highest at 3.35. The total sugar and reducing sugar contents changed greatly. The sugar addition increased, and the reducing sugar and total sugar also increased, which

Table 6. physicochemical properties of ginger brandy and its base wine with different sugar addition

\begin{tabular}{ccccccc}
\hline & & \multicolumn{4}{c}{ Different sugar addition $(\mathrm{g} / \mathrm{L})$} \\
\cline { 3 - 6 } & & 85 & 102 & 119 & 136 & 153 \\
\hline & Alcohol content $(\%)$ & $5.12 \pm 0.00 \mathrm{e}$ & $6.04 \pm 0.00 \mathrm{~d}$ & $7.02 \pm 0.01 \mathrm{c}$ & $7.90 \pm 0.01 \mathrm{~b}$ & $9.05 \pm 0.00 \mathrm{a}$ \\
$\mathrm{pH}$ & 3.31 & 3.34 & 3.35 & 3.35 & 3.34 \\
Base & Reducing Sugar $(\mathrm{g} / \mathrm{L})$ & $1.53 \pm 0.03 \mathrm{e}$ & $2.41 \pm 0.01 \mathrm{~d}$ & $3.17 \pm 0.00 \mathrm{c}$ & $4.96 \pm 0.01 \mathrm{~b}$ & $5.58 \pm 0.03 \mathrm{a}$ \\
wine & Total Sugar $(\mathrm{g} / \mathrm{L})$ & $2.23 \pm 0.02 \mathrm{e}$ & $2.80 \pm 0.00 \mathrm{~d}$ & $3.67 \pm 0.05 \mathrm{c}$ & $5.17 \pm 0.02 \mathrm{~b}$ & $6.18 \pm 0.11 \mathrm{a}$ \\
& Total Acidity $(\mathrm{g} / \mathrm{L})$ & $7.75 \pm 0.00 \mathrm{a}$ & $6.87 \pm 0.00 \mathrm{c}$ & $6.73 \pm 0.00 \mathrm{~d}$ & $6.72 \pm 0.00 \mathrm{~d}$ & $6.88 \pm 0.00 \mathrm{~b}$ \\
& gingerol $(\mathrm{mg} / \mathrm{L})$ & $44.36 \pm 0.05 \mathrm{~b}$ & $43.32 \pm 0.12 \mathrm{c}$ & $42.14 \pm 0.03 \mathrm{e}$ & $45.22 \pm 0.03 \mathrm{a}$ & $43.12 \pm 0.09 \mathrm{~d}$ \\
\cline { 2 - 7 } & Alcohol content (\%) & 34 & 34 & 34 & 34 & 34 \\
Brandy & Total Acidity $(\mathrm{g} / \mathrm{L})$ & $0.37 \pm 0.003 \mathrm{a}$ & $0.36 \pm 0.000 \mathrm{~b}$ & $0.32 \pm 0.000 \mathrm{~d}$ & $0.31 \pm 0.002 \mathrm{e}$ & $0.35 \pm 0.002 \mathrm{c}$ \\
& Total ester $(\mathrm{g} / \mathrm{L})$ & $1.17 \pm 0.008 \mathrm{a}$ & $0.99 \pm 0.002 \mathrm{~b}$ & $0.97 \pm 0.001 \mathrm{c}$ & $0.88 \pm 0.001 \mathrm{~d}$ & $0.87 \pm 0.003 \mathrm{~d}$ \\
& Volatile acid $(\mathrm{g} / \mathrm{L})$ & $0.11 \pm 0.001 \mathrm{a}$ & $0.09 \pm 0.000 \mathrm{~b}$ & $0.08 \pm 0.001 \mathrm{c}$ & $0.06 \pm 0.000 \mathrm{~d}$ & $0.06 \pm 0.000 \mathrm{~d}$ \\
\hline
\end{tabular}

might be related to yeast fermentation. The high sugar addition made the yeast incomplete utilization, and the total sugar and reducing sugar left in the final wine also increased. After alcohol contents of all samples were adjusted to $34 \%$, it could be found that ginger brandy with sugar addition at $85 \mathrm{~g} / \mathrm{L}$ had the highest total acidity at $0.37 \mathrm{~g} / \mathrm{L}$ while that with sugar addition at $136 \mathrm{~g} / \mathrm{L}$ had the lowest total acidity at $0.31 \mathrm{~g} / \mathrm{L}$. The total ester of ginger pomace brandy correlates well with volatile acid contents $(r=0.976, p<0.01)$. The total ester of ginger pomace brandy decreased with the increasing sugar addition. When the sugar addition was $85 \mathrm{~g} / \mathrm{L}$, the total ester was highest at $1.17 \mathrm{~g} / \mathrm{L}$. On contrary, when the sugar addition was $153 \mathrm{~g} / \mathrm{L}$, the total ester was lowest at $0.87 \mathrm{~g} / \mathrm{L}$. Besides, when the sugar addition was $85 \mathrm{~g} / \mathrm{L}$, the volatile acids were highest at $0.11 \mathrm{~g} / \mathrm{L}$.

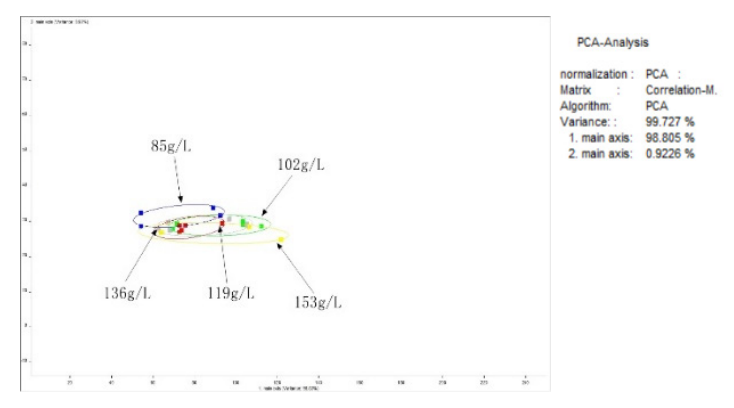

Figure 5. PCA load diagram of ginger pomace brandy electronic nose with different sugar addition

\subsubsection{Principal component analysis of ginger pomace brandy with different sugar addition by using electronic nose}

Principal component analysis of ginger pomace brandy with different sugar addition by using electronic nose was presented in the Figure 5. The contribution rate of the first principal component (PC1) was $98.805 \%$, while the contribution rate of the second principal component (PC2) was $0.9226 \%$, and and the total contribution rate of $\mathrm{PC} 1$ and PC2 was $99.727 \%$, which was much higher than $85 \%$. Besides, it was found that their PCA load diagrams were 
overlapped and could not be separated, indicating that these five ginger pomace brandies were similar in aroma. Consequently, it could be concluded that sugar addition had little effect on the aroma of ginger pomace brandy.

\subsubsection{Sensory evaluation of ginger pomace brandy with different sugar addition}

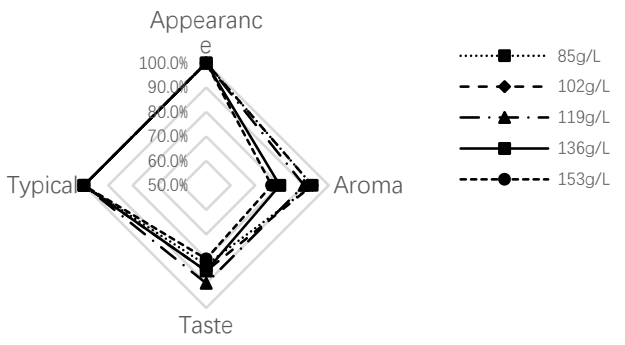

Sensory evaluation of ginger pomace brandy with five sugar addition was shown in Figure 6. For the aroma, when the alcohol contents of base wine were at $85 \mathrm{~g} / \mathrm{L}$ and $102 \mathrm{~g} / \mathrm{L}$, their corresponding brandies got higher aroma score and higher evaluation. When the alcohol content of base wine was at $153 \mathrm{~g} / \mathrm{L}$, corresponding brandy got lowest score. It might be due to that the brandy was concentrated and its aroma was more prominent when the alcohol content of its base wine was low. From the perspective of taste, brandy with $153 \mathrm{~g} / \mathrm{L}$ sugar addition had the lowest score. The base wine with higher alcohol content concentration could produce higher brandy volume consequently, the brandy had low aroma concentration and flat taste. The brandy with $102 \mathrm{~g} / \mathrm{L}$ sugar addition had concentrated aroma, strong and balanced taste, proper gingerol strength, and typicity of ginger pomace brandy.

Figure 6. Radar chart of sensory score of ginger pomace brandy with different sugar addition

Table 7. quality ranking results of five different sugar addition of ginger brandy by 11 quality cuppers

\begin{tabular}{cccccc}
\hline Cuppers & \multicolumn{5}{c}{ Sugar addition $(\mathrm{g} / \mathrm{L})$} \\
\cline { 2 - 5 } & 85 & 102 & 119 & 136 & 153 \\
\hline 1 & 4 & 1 & 3 & 2 & 5 \\
3 & 2 & 1 & 3 & 4 & 5 \\
4 & 3 & 1 & 2 & 3 & 5 \\
5 & 3 & 2 & 1 & 2 & 5 \\
6 & 3 & 1 & 4 & 1 & 4 \\
7 & 3 & 2 & 5 & 5 & 5 \\
8 & 3 & 4 & 2 & 5 & 4 \\
9 & 3 & 2 & 1 & 4 & 4 \\
10 & 3 & 1 & 2 & 4 & 5 \\
11 & 2 & 3 & 1 & 35 & 5 \\
Sum of ranks & 3 & 2 & 25 & $\mathrm{~B}$ & 52 \\
Significance & 32 & 20 & $\mathrm{~B}$ & & $\mathrm{~A}$ \\
\hline
\end{tabular}

Ranking results and significant difference from the cuppers were shown in Table 7. Through the sum of ranks, it could be concluded that ginger pomace brandy with 102 $\mathrm{g} / \mathrm{L}$ sugar addition was the most popular.

\subsection{Effects of different yeast addition on the physicochemical properties and sensory evaluation of ginger brandy and its base wine}

\subsubsection{Effects of different yeast addition on the physicochemical properties of ginger brandy and its base wine}

The physicochemical properties of ginger brandy base wines with different yeast addition were shown in Table 8 . The alcohol contents of various sugar addition were different; the alcohol content was highest at $6.23 \mathrm{~g} / \mathrm{L}$ when the yeast addition was $0.45 \mathrm{~g} / \mathrm{L}$ while the alcohol content was lowest at $5.95 \mathrm{~g} / \mathrm{L}$ when the yeast addition was 0.25 $\mathrm{g} / \mathrm{L}$. With the increasing yeast addition, the total acidity increased, and the $\mathrm{pH}$ decreased. The total acidity was highest at $7.85 \mathrm{~g} / \mathrm{L}$ when the yeast addition was $0.45 \mathrm{~g} / \mathrm{L}$ while it was lowest at $6.85 \mathrm{~g} / \mathrm{L}$ when the yeast addition was $0.25 \mathrm{~g} / \mathrm{L}$. When the yeast addition was $0.25 \mathrm{~g} / \mathrm{L}$, the total sugar and reducing sugar left in the final brandy were highest, which might be due to that the fermentation was restricted by limited yeast addition, leading to low alcohol content production and high total sugar and reducing sugar contents. When the alcohol content of ginger pomace brandy was adjusted to $35 \%$ after second distillation and the total acidity of base wine corelates well with total acidity, total ester, and volatile acids of brandy $(p<0.05)$, which increased with the increasing yeast addition. When the yeast addition was $0.45 \mathrm{~g} / \mathrm{L}$, the total acidity, total easter, and volatile acids were highest at $0.35 \mathrm{~g} / \mathrm{L}, 1.08 \mathrm{~g} / \mathrm{L}$, and $0.15 \mathrm{~g} / \mathrm{L}$, respectively. By contrast, when the yeast addition was $0.25 \mathrm{~g} / \mathrm{L}$, the total acidity, total easter, and 
volatile acids were lowest at $0.31 \mathrm{~g} / \mathrm{L}, 0.94 \mathrm{~g} / \mathrm{L}$, and $0.10 \mathrm{~g} / \mathrm{L}$, respectively.

Table 8. Physicochemical properties of ginger pomace base wine and ginger pomace brandy with different yeast addition

\begin{tabular}{|c|c|c|c|c|c|c|}
\hline & & \multicolumn{5}{|c|}{ Different yeast addition $(\mathrm{g} / \mathrm{L})$} \\
\hline & & 0.25 & 0.30 & 0.35 & 0.40 & 0.45 \\
\hline \multirow{6}{*}{$\begin{array}{l}\text { Base } \\
\text { wine }\end{array}$} & Alcohol content (\%) & $5.95 \pm 0.00 \mathrm{e}$ & $6.01 \pm 0.01 \mathrm{~d}$ & $6.15 \pm 0.00 \mathrm{~b}$ & $6.09 \pm 0.01 \mathrm{c}$ & $6.23 \pm 0.01 \mathrm{a}$ \\
\hline & $\mathrm{pH}$ & 3.35 & 3.30 & 3.28 & 3.24 & 3.24 \\
\hline & Reducing Sugar $(\mathrm{g} / \mathrm{L})$ & $5.02 \pm 0.00 \mathrm{a}$ & $1.41 \pm 0.01 \mathrm{e}$ & $2.17 \pm 0.01 \mathrm{~d}$ & $3.06 \pm 0.00 \mathrm{~b}$ & $2.58 \pm 0.01 \mathrm{c}$ \\
\hline & Total Sugar $(g / L)$ & $5.65 \pm 0.02 \mathrm{a}$ & $1.60 \pm 0.00 \mathrm{e}$ & $2.37 \pm 0.01 \mathrm{~d}$ & $3.12 \pm 0.01 \mathrm{~b}$ & $2.75 \pm 0.01 \mathrm{c}$ \\
\hline & Total Acidity $(\mathrm{g} / \mathrm{L})$ & $6.85 \pm 0.00 \mathrm{~d}$ & $7.08 \pm 0.00 \mathrm{c}$ & $7.33 \pm 0.00 \mathrm{~b}$ & $7.80 \pm 0.01 \mathrm{a}$ & $7.85 \pm 0.02 \mathrm{a}$ \\
\hline & gingerol (mg/L) & $45.26 \pm 0.00 \mathrm{a}$ & $46.32 \pm 0.03 b$ & $43.23 \pm 0.05 \mathrm{c}$ & $44.30 \pm 0.00 \mathrm{c}$ & $44.85 \pm 0.05 \mathrm{~d}$ \\
\hline \multirow{4}{*}{ Brandy } & Alcohol content $(\%)$ & 35 & 35 & 35 & 35 & 35 \\
\hline & Total Acidity $(\mathrm{g} / \mathrm{L})$ & $0.31 \pm 0.002 \mathrm{c}$ & $0.32 \pm 0.002 b$ & $0.35 \pm 0.002 \mathrm{a}$ & $0.35 \pm 0.000 \mathrm{a}$ & $0.35 \pm 0.002 \mathrm{a}$ \\
\hline & Total ester $(\mathrm{g} / \mathrm{L})$ & $0.94 \pm 0.002 \mathrm{~d}$ & $0.96 \pm 0.002 \mathrm{c}$ & $0.97 \pm 0.000 \mathrm{~b}$ & $1.07 \pm 0.002 \mathrm{a}$ & $1.08 \pm 0.003 \mathrm{a}$ \\
\hline & Volatile acid (g/L) & $0.10 \pm 0.001 \mathrm{~d}$ & $0.11 \pm 0.010 \mathrm{c}$ & $0.11 \pm 0.010 \mathrm{c}$ & $0.13 \pm 0.000 \mathrm{~b}$ & $0.15 \pm 0.000 \mathrm{a}$ \\
\hline
\end{tabular}

\subsubsection{Principal component analysis of ginger pomace brandy with different yeast addition by using electronic}

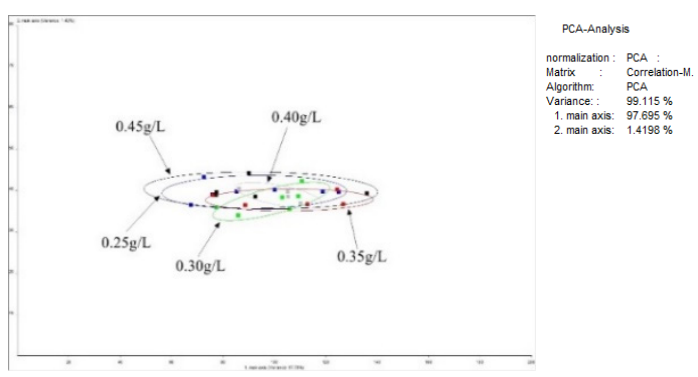

Figure 7. PCA load diagram of ginger pomace brandy electronic nose with different yeast addition

Principal component analysis of ginger pomace brandy with different sugar addition by using electronic nose was presented in the Figure 7. The contribution rate of the first principal component (PC1) was 97.695\% while the contribution rate of the second principal component (PC2) was $1.4198 \%$, and the total contribution rate of $\mathrm{PC} 1$ and PC2 was $99.115 \%$, which was much higher than $85 \%$. The two principal components could represent the main volatile components of ginger pomace brandy, which meant the results were reliable. Besides, it was found that their PCA load diagrams were overlapped and could not be separated, indicating that these five ginger pomace brandies were similar in aroma. Consequently, it could be concluded that yeast addition had little effect on the aroma of ginger pomace brandy.

Table 9 Quality ranking results of five different yeast addition of ginger brandy by 11 quality cuppers

\begin{tabular}{|c|c|c|c|c|c|}
\hline \multirow{2}{*}{ Cuppers } & \multicolumn{5}{|c|}{ Yeast addition $(\mathrm{g} / \mathrm{L})$} \\
\hline & 0.25 & 0.30 & 0.35 & 0.40 & 0.45 \\
\hline 1 & 3 & 4 & 2 & 1 & 5 \\
\hline 2 & 4 & 3 & 2 & 1 & 5 \\
\hline 3 & 5 & 4 & 1 & 2 & 3 \\
\hline 4 & 5 & 4 & 1 & 2 & 3 \\
\hline 5 & 4 & 3 & 2 & 1 & 5 \\
\hline 6 & 5 & 4 & 1 & 2 & 3 \\
\hline 7 & 5 & 4 & 3 & 1 & 2 \\
\hline
\end{tabular}

\subsubsection{Sensory evaluation of ginger pomace brandy with different yeast addition}

Sensory evaluation of ginger pomace brandy with different yeast addition was shown in Figure 8. In general, brandy with $0.25 \mathrm{~g} / \mathrm{L}$ yeast addition got the lowest appearance score. Brandies with $0.25 \mathrm{~g} / \mathrm{L}$ and $0.45 \mathrm{~g} / \mathrm{L}$ yeast addition got the lowest aroma score while brandy with $0.40 \mathrm{~g} / \mathrm{L}$ yeast addition got the highest score. For the taste, brandy with $0.40 \mathrm{~g} / \mathrm{L}$ yeast addition got the highest score while brandy with $0.25 \mathrm{~g} / \mathrm{L}$ yeast addition got the lowest score. All these five samples had the typical ginger flavor and scored $100 \%$. Overall, ginger pomace brandy with $0.40 \mathrm{~g} / \mathrm{L}$ yeast addition got the highest total score. Ranking results and significant difference from the cuppers were shown in Table 9. Through the sum of ranks, it could be concluded that ginger pomace brandy with 0.40 $\mathrm{g} / \mathrm{L}$ yeast addition was the most popular. 


\begin{tabular}{cccccc}
8 & 4 & 5 & 1 & 2 & 3 \\
9 & 4 & 5 & 1 & 2 & 3 \\
10 & 3 & 4 & 5 & 2 & 1 \\
11 & 3 & 4 & 5 & 2 & 1 \\
Sum of ranks & 45 & 44 & 24 & 18 & 34 \\
Significance & $\mathrm{A}$ & $\mathrm{A}$ & $\mathrm{BC}$ & $\mathrm{CD}$ & $\mathrm{B}$ \\
\hline
\end{tabular}

Table 10. Physicochemical properties of ginger brandy and its base wine with different fermentation temperature

\begin{tabular}{ccccccc}
\hline & & \multicolumn{4}{c}{ Fermentation temperature $\left({ }^{\circ} \mathrm{C}\right)$} \\
\cline { 3 - 6 } & & 16 & 18 & 20 & 22 & 24 \\
\hline \multirow{3}{*}{} & Alcohol content $(\%)$ & $6.08 \pm 0.00 \mathrm{e}$ & $6.24 \pm 0.00 \mathrm{c}$ & $6.15 \pm 0.00 \mathrm{~d}$ & $6.33 \pm 0.01 \mathrm{~b}$ & $6.39 \pm 0.00 \mathrm{a}$ \\
& Fermentation time $(\mathrm{d})$ & $25 \mathrm{~d}$ & $20 \mathrm{~d}$ & $17 \mathrm{~d}$ & $17 \mathrm{~d}$ & $16 \mathrm{~d}$ \\
BH & 3.14 & 3.10 & 3.09 & 3.08 & 3.07 \\
Base & Reducing Sugar $(\mathrm{g} / \mathrm{L})$ & $4.58 \pm 0.01 \mathrm{a}$ & $3.61 \pm 0.01 \mathrm{~b}$ & $3.47 \pm 0.11 \mathrm{c}$ & $3.16 \pm 0.01 \mathrm{~d}$ & $1.58 \pm 0.01 \mathrm{e}$ \\
& Total Sugar $(\mathrm{g} / \mathrm{L})$ & $5.93 \pm 0.02 \mathrm{a}$ & $3.70 \pm 0.02 \mathrm{c}$ & $3.89 \pm 0.01 \mathrm{~b}$ & $3.33 \pm 0.02 \mathrm{~d}$ & $1.99 \pm 0.01 \mathrm{e}$ \\
& Total Acidity $(\mathrm{g} / \mathrm{L})$ & $7.65 \pm 0.01 \mathrm{e}$ & $7.79 \pm 0.00 \mathrm{~d}$ & $7.85 \pm 0.00 \mathrm{c}$ & $8.01 \pm 0.00 \mathrm{~b}$ & $8.18 \pm 0.00 \mathrm{a}$ \\
& gingerol $(\mathrm{mg} / \mathrm{L})$ & $45.36 \pm 0.03 \mathrm{e}$ & $48.32 \pm 0.05 \mathrm{c}$ & $47.14 \pm 0.03 \mathrm{~d}$ & $49.22 \pm 0.00 \mathrm{~b}$ & $50.12 \pm 0.05 \mathrm{a}$ \\
\cline { 2 - 7 } Brandy & Alcohol content $(\%)$ & 29 & 29 & 29 & 29 & 29 \\
& Total Acidity $(\mathrm{g} / \mathrm{L})$ & $0.31 \pm 0.002 \mathrm{e}$ & $0.32 \pm 0.007 \mathrm{~d}$ & $0.35 \pm 0.002 \mathrm{c}$ & $0.36 \pm 0.002 \mathrm{~b}$ & $0.39 \pm 0.002 \mathrm{a}$ \\
& Total ester $(\mathrm{g} / \mathrm{L})$ & $0.85 \pm 0.002 \mathrm{e}$ & $0.98 \pm 0.002 \mathrm{~d}$ & $1.00 \pm 0.002 \mathrm{c}$ & $1.07 \pm 0.002 \mathrm{~b}$ & $1.11 \pm 0.003 \mathrm{a}$ \\
& Volatile acids $(\mathrm{g} / \mathrm{L})$ & $0.05 \pm 0.001 \mathrm{~d}$ & $0.09 \pm 0.010 \mathrm{c}$ & $0.11 \pm 0.010 \mathrm{~b}$ & $0.14 \pm 0.010 \mathrm{a}$ & $0.14 \pm 0.000 \mathrm{a}$ \\
\hline
\end{tabular}

\subsection{Effects of fermentation temperature on the physicochemical properties and sensory evaluation of ginger brandy and its base wine}

\subsubsection{Effects of fermentation temperature on the physicochemical properties of ginger brandy and its base wine}

Physicochemical properties of ginger pomace brandy and its base wine with different fermentation temperature were shown in Table 10. The alcohol contents of ginger pomace base wine were from $6.08 \%$ to $6.39 \%$. Total acidity increased with the improved fermentation temperature. The base wine had highest total acidity at $8.18 \mathrm{~g} / \mathrm{L}$ when the fermentation temperature was $24^{\circ} \mathrm{C}$ while it had lowest total acidity at $7.65 \mathrm{~g} / \mathrm{L}$. When the fermentation temperature was $16^{\circ} \mathrm{C}$. the lower the alcohol content was $6.08 \%$, the higher the total sugar and reducing sugar were $5.93 \mathrm{~g} / \mathrm{L}$ and $4.58 \mathrm{~g} / \mathrm{L}$, the lower the total acidity was 7.65 $\mathrm{g} / \mathrm{L}$. It might be due to that with the increasing temperature $\left(16-24^{\circ} \mathrm{C}\right)$, the yeasts were closer to optimum fermentation temperature. Consequently, the yeast had stronger fermentation ability, and then consumed more sugar and produced more alcohol content. After alcohol contents of all samples were adjusted to $34 \%$, the acidity of base wine correlates well with that of brandy $(\mathrm{r}=0.971$, $\mathrm{p}<0.01$ ). The brandy had highest total acidity at $0.39 \mathrm{~g} / \mathrm{L}$ when the fermentation temperature was $24^{\circ} \mathrm{C}$ while it had lowest total acidity at $0.31 \mathrm{~g} / \mathrm{L}$ when the fermentation temperature was $16^{\circ} \mathrm{C}$. The brandy had highest total ester and volatile acids at 1.11 and $0.14 \mathrm{~g} / \mathrm{L}$, respectively, when the fermentation temperature was $24^{\circ} \mathrm{C}$ while it had lowest total acidity and volatile acids at 0.31 and $0.05 \mathrm{~g} / \mathrm{L}$, respectively when the fermentation temperature was $16^{\circ} \mathrm{C}$.

\subsubsection{Principal component analysis of ginger pomace brandy with different fermentation temperatures by using electronic nose}

Principal component analysis of ginger pomace brandy with different fermentation temperature by using electronic nose was presented in the Figure 9. The contribution rate of the first principal component (PC1) was $92.66 \%$, while the contribution rate of the second principal component (PC2) was $5.1425 \%$, and the total contribution rate of $\mathrm{PC} 1$ and $\mathrm{PC} 2$ was $97.803 \%$, which was much higher than $85 \%$. It was found that their PCA load diagrams were partial overlapped, indicating that these five ginger pomace brandies were similar in aroma.

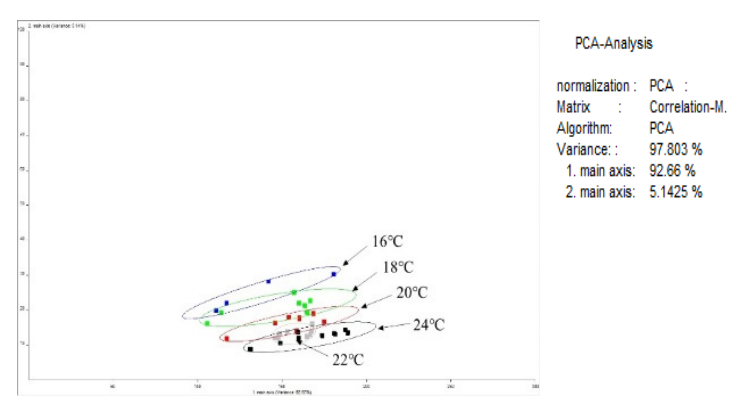

Figure 9. PCA load diagram of ginger pomace brandy with different fermentation temperature by using electronic nose 


\subsubsection{Sensory evaluation of ginger pomace brandy with different fermentation temperatures}
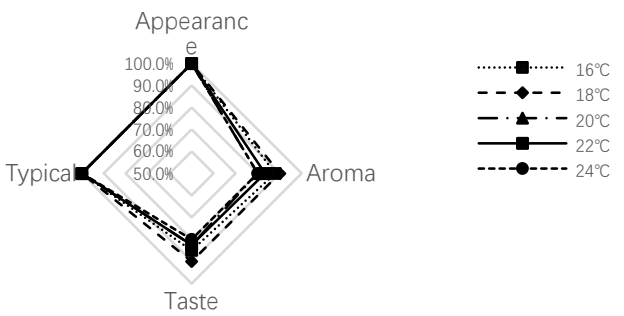

Figure 10. Radar chart of sensory score of ginger pomace brandy with different fermentation temperatures

Sensory evaluation of ginger pomace brandy with different fermentation temperatures was shown in Figure 10. All these samples had crystal clear appearance. Brandies with fermentation temperatures at $16^{\circ} \mathrm{C}$ and $18^{\circ} \mathrm{C}$ had the highest aroma score, which might be due to that the longer fermentation time led to extract more aroma from the ginger pomace. The brandy had highest taste score when the fermentation temperature was $16^{\circ} \mathrm{C}$ while it had lowest taste score when the fermentation temperature was $24^{\circ} \mathrm{C}$. All these five samples had the typical ginger flavor and scored $100 \%$ without great drawbacks. Brandy with the fermentation temperature at $18^{\circ} \mathrm{C}$ had pleasant flavor, prominent ginger aroma, full body, proper gingerol strength and best typicity.

Ranking results from the cuppers was shown in Table 11. Through the sum of ranks, it could be concluded that ginger pomace brandy with fermentation temperature at $18^{\circ} \mathrm{C}$ was the most popular.

Table 11 Quality ranking results of five different fermentation temperature of base wine of ginger brandy by 11 quality cuppers

\begin{tabular}{cccccc}
\hline \multirow{2}{*}{ Cuppers } & \multicolumn{5}{c}{ Fermentation temperature $\left({ }^{\circ} \mathrm{C}\right)$} \\
\cline { 2 - 6 } & 16 & 18 & 20 & 22 & 24 \\
\hline 1 & 4 & 1 & 3 & 2 & 5 \\
2 & 2 & 1 & 3 & 4 & 5 \\
3 & 3 & 1 & 2 & 4 & 5 \\
4 & 4 & 2 & 1 & 3 & 5 \\
5 & 3 & 1 & 4 & 2 & 5 \\
6 & 2 & 3 & 5 & 1 & 4 \\
7 & 1 & 2 & 4 & 3 & 5 \\
8 & 3 & 2 & 1 & 5 & 4 \\
9 & 3 & 1 & 2 & 5 & 4 \\
10 & 2 & 3 & 1 & 4 & 5 \\
11 & 3 & 2 & 5 & 2 & 1 \\
Sum of ranks & 30 & 19 & 31 & 35 & 48 \\
Significance & $\mathrm{BC}$ & $\mathrm{CD}$ & $\mathrm{BC}$ & $\mathrm{B}$ & $\mathrm{A}$ \\
\hline
\end{tabular}

\section{CONCLUSIONS}

The $\mathrm{pH}$ and total acidity of ginger brandy base wine were mainly influenced by ginger pomace/water ratio, yeast strain selection, sugar and yeast addition, fermentation temperature. While the gingerol content were mostly affected by ginger pomace/water ratio. The results of electronic nose analysis showed that main aroma components of ginger pomace brandy were mainly affected by ginger pomace/water ratio. In general, the optimized production technique was ginger pomace/water ratio at 1:3,3\# yeast strain, sugar and yeast addition (102 $\mathrm{g} / \mathrm{L}$ and $0.40 \mathrm{~g} / \mathrm{L})$, fermentation temperature $\left(18^{\circ} \mathrm{C}\right)$. Ginger brandy base wine made by above technique after second full distillation could produce ginger brandy with typical, strong and balanced ginger aroma, mellow and full-bodied taste, and long aftertaste.

\section{REFERENCES}

1. M. Chen, T. He, C.H., Ren,. The Yangtze river vegeTable: 02, 3-4(2021).

2. Y. Shukla, M. Singh, FOOD CHEM TOXICOL, 45 : 683-690 (2007).

3. R. Kiyama, J NUTR BIOCHEM, 86: 108486 (2020).

4. B.H. Ali, G. Blunden, M.O. Tanira, FOOD CHEM TOXICOL, 46, 409-420 (2008).

5. X. He, M.W. Bernart, L. Lian, L. Lin, $J$ CHROMATOGR A, 796: 327-334 (1998).

6. A. Zahoor, C. Yang, Y. Yang, Y. Guo, T. Zhang, K. Jiang, S. Guo, G. Deng, PHYTOMEDICINE (2020)

7. C. Sampath, M.R. Rashid, S. Sang, M. Ahmedna. FOOD CHEM, 226, 79-88 (2017).

8. M. Zarei, P Acharya, R.R. Talahalli. LIFE SCI, 265: 118856 (2021).

9. S. Malmir, A. Ebrahimi, F. Mahjoubi. GENE REPORTS, 21: 100824 (2020).

10. H.Y. Yeh, C.H. Chuang, H.C. Chen, C.J. Wan, T.L. Chen, L.Y. Lin, LWT-FOOD SCI TECHNOL, 55, 329-334 (2014).

11. B. Huang, G. Wang, Z. Chu, L. Qin, DRY TECHNOL, 30, 248-255 (2012).

12. N.M. Adelina, H. Wang, L. Zhang, Y. Zhao, FOOD RES INT, 140: 110026 (2021).

13. J.F. Bi, Practical handbook of sensory evaluation, 99103 (2016). 